\title{
Analisis Sistem informasi Manajemen dalam Penanganan Gangguan Keamanan Bandara
}

(Studi Kasus pada Unit Aviation Security Bandar Udara Binaka Kota Gunungsitoli)

\author{
Maria Magdalena Bate'e \\ Sekolah Tinggi Ilmu Ekonomi Pembangunan Nasional \\ maria.batee82@gmail.com
}

\begin{abstract}
Abstrak
Poin terpenting dalam penelitian ini adalah menganalisis Sistem Informasi Manajemen dalam menangani setiap kasus pelanggaran yang terjadi di Bandara Binaka, apa yang dimaksud dengan pelangaran melawan hukum serta apa saja jenis pelanggaran tersebut, dan bagaimana Standar Operasional Prosedur petugas pengamanan Bandara Binaka dalam mengamankan Bandara dari tindakan melawan hukum. Jenis penelitian yang digunakan dalam penelitian ini adalah jenis penelitian kualitatif deskriptif. Yang menjadi populasi dalam penelitian ini adalah seluruh anggota aviation security Bandar Udara Binaka Gunungsitoli berjumlah 24 orang, dan sampel dalam penelitian ini diambil berdasarkan pengambilan sampel secara insidental. Kemudian jenis data yang digunakan peneliti dalam penelitian ini yaitu data primer dan data sekunder. Kedua jenis data ini dapat diperoleh dengan cara observasi dan wawancara. Selanjutnya, data yang sudah diperoleh dari objek penelitian akan dianalisa dengan teknik analisa data deskriptif kualitatif. Hasil dari penelitian ini yakni Bandara Binaka memiliki Sistem pengamanan yang disebut dengan Airport Safety yang digunakan oleh petugas AVSEC Bandara dalam menjalankan SOP penanganan gangguan keamanan Bandara, dengan menggunakan tegnologi-tegnologi yang canggih seperti $\mathrm{x}$-ray, WTMD, HHMD, radar, CCTV dan peralatan canggih lainnya.
\end{abstract}

Kata Kunci Sistem Informasi Manajemen, Aviation Security Bandara

\section{PENDAhuluan}

Perkembangan ilmu pengetahuan dan teknologi mengakibatkan keinginan dan kebutuhan manusia semakin bertambah. Keinginan dan kebutuhan manusia pada zaman modern ini demikian banyaknya, sehingga tidak mungkin dapat dipenuhi dengan berusaha sendiri. Oleh sebab itu manusia membentuk suatu wadah yaitu organisasi dengan tujuan untuk mencapai tujuan secara bersama-sama.

Setiap organisasi baik yang dikelola oleh pemerintah maupun swasta selalu berorientasi pada pencapaian tujuan seoptimal mungkin dan tentunya ini dapat dilihat dari sistem informasi manajemen yang diterapkan oleh setiapa organisasi itu sendiri. Sistem informasi manajemen diterapkan untuk memenuhi kebutuhan manajemen dalam pengambilan keputusan yang diperlukan untuk peningkatan produktivitas pegawai. Karena salah satu kebijakan yang penting yang menjadi prioritas utama setiap organisasi adalah investasi di bidang pengembangan sumber daya manusia. Dengan demikian, agar tercapai tujuan yang telah ditetapkan secara efektif, maka suatu organisasi hendaknya dapat menyusun suatu struktur atau hubungan pekerjaan tertentu di antara bermacam-macam komponen dari kesatuan secara keseluruhan. Dalam hal ini sistem informasi manajemen merupakan suatu kerangka yang mempolakan hubungannya di antara orang-orang maupun bidang-bidang kerja dalam organisasi tersebut sehingga jelas kedudukan, wewenang dan tanggungjawabnya masing-masing dalam suatu kebulatan yang teratur.

Bandar udara (bandara) memegang peranan penting bagi suatu negara maupun daerah. Bandara merupakan gerbang atau pintu masuk dari suatu daerah atau sebagai fasilitator yang menghubungkan antara daerah satu dengan daerah lainnya. Peran bandar udara menurut Dirjen 
Perhubungan Udara diantaranya: sebagai simpul dalam jaringan transportasi udara sesuai hierarki bandar udara, pintu gerbang kegiatan perekonomian, tempat kegiatan alih moda transportasi, pendorong dan penunjang kegiatan industri, perdagangan dan/atau pariwisata, pembuka isolasi daerah, serta prasarana memperkokoh wawasan nusantara dan kedaulatan negara.

Bandara merupakan pelabuhan moda transportasi udara yang merupakan jenis moda transportasi yang cukup diminati masyarakat saat ini karena menawarkan kenyamanan dan efisiensi waktu, terlebih dengan munculnya maskapai penerbangan yang menawarkan jasa angkutan udara dengan biaya yang cukup terjangkau.

Berdasarkan Peraturan Menteri Perhubungan No. 139 tahun 2011 tentang Keselamatan Penerbangan Sipil menjelaskan bahwa setiap penyelenggara bandar udara memiliki kewajiban untuk menaati peraturan perundang-undangan dan ketentuan dibidang kebandarudaraan, lalu lintas udara, keamanan dan keselamatan penerbangan serta pengelolaan lingkungan. Penyelenggara bandar udara harus dapat melindungi bandar udara dari segala bentuk tindakan yang mengancam keamanan dan keselamatan penerbangan. Untuk itu setiap bandar udara harus memiliki suatu unit kerja yang bertugas untuk memelihara, melindungi dan mengamankan manusia dan material secara fisik dari segala bentuk ancaman keamanan yang ditimbulkan oleh manusia dan barang di daerah lingkungan kerja bandar udara, yakni Unit Pengamanan Penerbangan atau aviation security (avsec).

Walaupun gangguan keselamatan dan keamanan di bandara Binaka Gunungsitoli belum pernah mengalami gangguan yang sangat serius, namun Standard Operational Procedur (SOP) keamanan tetap dijalankan untuk menghindari hal-hal yang tidak diinginkan. Secara sederhana, status keamanan penerbangan terbagi menjadi tiga, yaitu: pertama, status hijau berarti kondisi keamanan penerbangan dalam keadaan normal; kedua yaitu status kuning, berarti kondisi keamanan penerbangan dalam keadaan waspada; dan yang ketiga status merah, artinya kondisi keamanan penerbangan sedang dalam bahaya. Mengingat maraknya ancaman terorisme yang terjadi tak hanya di Indonesia, akan tetapi di seluruh dunia, kondisi keamanan penerbangan dalam negeri otomatis turut serta dalam keadaan terancam. Peningkatan Kondisi keamanan penerbangan nasional ini berupa meningkatkan status hijau kondisi normal bandara menjadi status kuning untuk antisipasi hal-hal yang memungkinkan menjadi ancaman terhadap sebuah bandara. Peningkatan status kuning bagi bandara di Indonesia ini adalah salah satu cara pemerintah melalui Dirjen Perhubungan Udara untuk memproteksi penerbangan di Indonesia.

Bandara Binaka Gunungsitoli juga tidak luput dari gangguan keamanan dalam berbagai bentuk. Dari laporan keamanan bandara (security incident and accident report) diketahui telah terjadi beberapa kali tindakan gangguan keamanan atau tindakan melawan hukum di Bandara Binaka Gunungsitoli, misalnya penumpang mengaku bawa bom, minuman keras dan narkoba, tiket yang tidak sesuai dengan indentitas penumpang, bebasnya akses masyarakat masuk di area landasan pacu dan lain sebagainya. Dengan kondisi seperti ini, maka peran pengamanan bandara perlu semakin ditingkatkan agar tidak terjadi hal-hal yang dapat melanggar hukum dan yang dapat berakibat fatal.

Berdasarkan fenomena yang telah dijabarkan di atas, maka penelitian ini bertujuan Untuk mengetahui sistem informasi manajemen Bandara Binaka Gunungsi, untuk mengetahui standar operasional prosedur penanganan keamanan Bandara Binaka Gunungsitoli, dan untuk mengetahui sistem informasi manajemen yang digunakan dalam penanganan gangguan keamanan Bandara Binaka Gunungsitoli.

\section{LANDASAN TEORI}

\section{Pengertian Sistem Informasi Manajemen}

Secara sederhana sistem informasi manajemen dapat diartikan sebagai suatu sistem yang berorientasi kepada upaya pengumpulan data, pengolahan data, analisa dan evaluasi. Ada beberapa pendapat para ahli mengenai system informasi manajemen. Menurut Davis (2015: 32), menyatakan bahwa: "sistem informasi manajemen adalah sebuah sistem manusia atau mesin yang terpadu untuk menyajikan informasi guna mendukung fungsi operasi manajemen dan 
pengambilan keputusan dalam sebuah organisasi." Pengertian yang berbeda dikemukakan oleh McLeod dan Schell (2017: 76) sebagai berikut: meyatakan bahwa "Sistem Informasi Manajemen merupakan sistem yang berbasis komputer, jaringan lainnya yang dapat menyediakan informasi bagi beberapa pemakai guna mendukung fungsi-fungsi manajemen dan fungsi pengambilan keputusan." Selanjutnya menurut Syamsi (2017: 100) menyatakan bahwa "Sistem Informasi Manajemen merupakan jaringan informasi yang dibutuhkan pimpinan dalam menjalankan tugasnya, terutama dalam mengambil keputusan dan juga merupakan cara-cara mengelola pekerjaan informasi dengan mengunakan pendekatan sistem yang berdasarkan pada prinsipprinsip manajemen.” Dan pendapat yang lain oleh George (2019: 201) menyatakan bahwa "Sistem Informasi Manajemen adalah serangkaian subsistem informasi yang menyeluruh dan terkoordinasi dan secara rasional terpadu yang mampu mentransformasikan data sehingga menjadi informasi lewat serangkaian cara guna meningkatkan produktivitas yang sesuai dengan gaya dan sifat pimpinan atas kriteria mutu yang telah ditetapkan." Jadi, dari beberapa pendapat para ahli di atas dapat disimpulkan bahwa sistem informasi manajemen sangat membantu tahapan manajemen dalam organisasi, mulai dari fungsi manajemen secara umum sampai ke tahap pengambilan keputusan. Artinya bahwa semua orang dalam organisasi yang berhubungan dengan manajemen bertanggungjawab atas kegiatan dan hasil organisasi, terutama bagi seorang pimpinan dalam mencapai suatu tujuan organisasi.

\section{Manfaat Sistem Infomasi Manajemen}

Para pemimpin yang bertugas di bidang perencanaan ataupun yang menangani bidang pengawasan dalam rangkaian usaha mengambil keputusan yang baik dan cepat, akan selalu membutuhkan informasi untuk mendukung kelancaran tugas-tugasnya. Oleh sebab itu informasi baru dapat dikatakan berguna apabila mampu berfungsi membantu pimpinan dalam pengambilan keputusan, terlebih dalam bidang perencanaan dan pengawasan, juga dalam penentuan program kerja.

Menurut Effendi (2015: 30) manfaat sistem informasi manajemen dapat diuraikan di bawah ini:

a. Sistem Informasi Manajemen sebagai Pembantu Dalam Pengambilan Keputusan.

Sebuah sistem informasi manajemen adalah sebuah sistem informasi yang melakukan semua pengolahan transaksi yang dibutuhkan serta memberikan dukungan informasi dan pengolahan untuk fungsi-fungsi manajemen dan pengambilan keputusan.

b. Sistem informasi manajemen sebagai Pendukung Fungsi Perencanaan dan Pengendalian.

Usaha mencapai tujuan bagi organisasi perusahaan adalah tercapainya tujuan perusahaan yang sesuai dengan perencanaan semula. Semua kegiatan dalam operasional akan selalu terlibat dalam proses perencanaan, baik itu perencanaan jangka pendek ataupun rencana jangka panjang. Sistem informasi manajemen sangat relevan bagi fungsi perencanaan. Perencanaan dan pengendalian yang dibantu dengan komputer memperlebar kemampuan manajemen untuk menyelengarakan fungsi yang penting ini. Kedua fungsi sangat erat kaitannya. Tanpa ada perencanaan, pengendalian tidak akan ada. Sedangkan apabila ada perencanaan tetapi tidak ada pengendalian, maka rencana tersebut akan gagal.

c. Sistem informasi manajemen sebagai Penentuan Program Kerja.

Perincian dalam program kerja selalu didasarkan kepada program yang harus didahulukan dan program mana yang dapat ditunda untuk sementara. Untuk menentukan skala prioritas kerja dengan tepat dibutuhkan data informasi tentang faktor tenaga kerja yang tersedia. Juga diperlukan informasi tepat tentang sumber pembiayaan, lokasi yang hendak dilaksanakan, sistem pelaporan sistem penilaian dan umpan balik yang hendak dipergunakan, keuntungankeuntungan yang akan diperoleh serta hasil yang diharapkan.

Semua kegiatan yang dilakukan oleh setiap organisasi pasti memerlukan informasi. Demikian pula sebaliknya, semua kegiatan akan menghasilkan informasi, baik yang digunakan oleh organisasi yang melaksanakan kegiatan tersebut maupun kegiatan lain diluar kegiatan 
organisasi yang bersangkutan, oleh karena itu informasi berguna untuk semua macam dan bentuk kegiatan dalam setiap organisasi.

Apabila sistem informasi manajemn dirancang dan dilaksanakan dengan baik, maka akan banyak manfaat yang bisa diperoleh pihak manajemen dalam organisasi yang berguna untuk membantu dan menunjang proses pengambilan keputusan dalam organisasi.

Menurut Peter F. Drucker (2017: 43) mengatakan bahwa peranan sistem informasi manajemen adalah "suatu rumusan yang digunakan oleh organisasi dalam mengolah berbagai informasi serta menyajikannya sebagai bahan pertimbangan bagi setiap individu yang melakukan setiap kegiatan dalam organisasi”.

Dengan demikian jelas bahwa manfaat dan peranan dari Sistem Informasi Manjemen sangat penting bagi organisasi, karena dapat menghasilkan keputusan yang tepat dalam rangka pencapaian tujuan organisasi.

\section{Pengertian Sistem Pengamanan Bandar Udara (Aviation Security Bandara)}

Pengertian pengamanan berdasarkan Keputusan Menteri Perhubungan No. 54 tahun 2014 menjelaskan bahwa pengamanan (security) adalah gabungan sumber daya manusia, fasilitas dan materil serta prosedur untuk melindungi penerbangan dari tindakan gangguan melawan hukum. Sedangkan upaya pengamanan (security control) adalah upaya pencegahan terhadap penyusupan senjata, bahan peledak atau bahan-bahan lain yang mungkin digunakan untuk melakukan tindakan gangguan melawan hukum.

Dari penjelasan di atas dapat disimpulkan bahwa sistem pengamanan bandar udara adalah upaya gabungan sumber daya manusia, fasilitas dan materi serta prosedur dalam suatu rangkaian unsur yang bekerja sama sebagai pencegahan terhadap penyusupan senjata, bahan peledak, atau bahanbahan lain di bandar udara yang mungkin digunakan untuk melakukan tindakan-tindakan melawan hukum, sehingga tercapai suatu tujuan yaitu melindungi penerbangan sipil dari tindakan melawan hokum (faktor penyebabnya eksternal).

Menurut Undang-undang Nomor 15 Tahun 1992 tentang penerbangan, keamanan penerbangan adalah keadaan yang terwujud dari penerbangan yang bebas dari gangguan / tindakan yang melawan hukum.

Selanjutnya, undang-undang Nomor 15 tahun 1992 tentang pasal 3, berbunyi: "Penyelenggara bandar udara bertanggung jawab terhadap keamanan dan keselamatan penerbangan serta kelancaran pelayanannya". Program nasional pengamanan penerbangan sipil bertujuan untuk melindungi keselamatan, keteraturan dan efisiensi penerbangan sipil di Indonesia dengan memberikan perlindungan terhadap penumpang, awak pesawat udara, para petugas di darat, masyarakat, pesawat udara dan instalasi di bandar udara dari tindakan melawan hukum serta memberikan perlindungan terhadap operator pesawat udara. Maksudnya setiap negara anggota harus mempunyai tujuan utama untuk melindungi keamanan penumpang, awak pesawat, petugas yang beroperasi di darat dan masyarakat umum dalam segala hal yang berhubungan dengan pengamanan terhadap tindakan yang melawan hukum pada penerbangan sipil.

Selain itu, prosedur sistem pengamanan bandar udara berdasarkan Keputusan Menteri Perhubungan No. 54 tahun 2004, tindakan melawan hukum (act of unlawful interference) adalah tindakan yang dikategorikan:

1. Tindakan kekerasan terhadap seseorang di atas pesawat udara dalam penerbangan yang dimungkinkan membahayakan keselamatan pesawat udara.

2. Menghancurkan atau merusak pesawat udara yang akan di operasikan sehingga menyebabkan pesawat udara tersebut tidak dapat terbang atau membahayakan keselamatan pesawat udara tersebut.

3. Menempatkan alat atau bahan di pesawat udara dengan cara apapun sehingga pesawat udara tersebut tidak dapat terbang, hancur atau membahayakan keselamatan selama penerbangan.

4. Menghancurkan atau merusak atau mengganggu operasi fasilitas navigasi penerbangan yang berakibat membahayakan keselamatan penerbangan.

5. Komunikasi informasi palsu yang berakibat membahayakan keselamatan penerbangan. 
6. Melakukan tindakan melawan hukum yang disertai dengan penggunaan peralatan zat atau bahan atau senjata.

Selain dari penjelasan di atas, bandar udara juga harus bertindak tegas kepada penumpang yang membawa barang-barang atau alat yang dapat digunakan untuk mengancam keselamatan penerbangan, karena berdasarkan Keputusan Menteri Nomor 14 Tahun 1989 Pasal 6, senjata api, senjata tajam serta benda-benda lain yang dapat dipakai untuk mengancam atau memaksakan kehendak dilarang dimasukkan atau ditempatkan di dalam kabin pesawat udara

Berdasarkan Surat Keputusan Menteri Nomor SKEP/100/VI/2003 bahwa dilarang membawa senjata api ke dalam kabin. Dan Segala jenis senjata api dan peluru dilaporkan kepada Petugas Pengamanan Bandara, senjata api dan peluru yang dibawa harus mempunyai surat izin kepemilikan/penguasaan senjata api dan peluru, peluru dikosongkan dari senjata api oleh pemiliknya/pemegangnya. Senjata api dan peluru diserahkan ke penumpang atau pemiliknya pada saat berada di pintu keluar ruang kedatangan dengan tanda bukti.

Untuk mencegah terjadinya segala tindakan yang melawan hukum yang dapat mengancam, mengganggu dan menghambat segala kegiatan yang terjadi di bandar udara maka sistem pengamanan dilakukan selama 24 jam.

\section{METODOLOGI PENELITIAN}

Penelitian ini dilakukan dengan menggunakan jenis penelitian deskriptif kualitatif, dimana penulis menganalisa serta menarik kesimpulan penelitian secara deskriptif dan sistematis berdasarkkan data dan informasi yang diperoleh. Menurut Arikunto (2016:234) bahwa penelitian deskriptif kualitatif adalah penelitian yang dimaksudkan untuk mengumpulkan informasi mengenai status gejala yang ada, yaitu keadaan gejala menurut apa adanya pada saat penelitian dilakukan. Populasi dalam penelitian ini adalah seluruh pegawai keamanan Bandar udara Binaka Guungsitoli (AVSEC) yang berjumlah 24 orang, sedangkan pengambilan sampel dilakukan secara incidental dengan teknik pengumpulan datanya melakukan observasi dan wawancara (Sujarweni, 2015).

\section{HASIL PENELITIAN}

\section{Hasil Pengamatan}

Bandar Udara Binaka Gunungsitoli sebagai salah satu bandara yang tidak pernah sepi dari penumpang yang menggunakan jasa transportasi udara ini telah memiliki Sistem Informasi Manajemen yang berstandar. Sistem informasi manajemen ini di kemas dalam satu sistem informasi yang disebut Airport safety. Airport safety ini merupakan sistem informasi yang berguna dalam kondisi kritis. Hal ini dimaksudkan bahwa Bandar Udara Binaka Gunungsitoli melakukan peningkatan keamanan bila terjadi kondisi kritis seperti kriminalitas, kebakaran, maupun ancaman bom. Kegiatan pengamanan bandara ini di lakukan oleh petugas pengamanan bandara yang disebut Aviation Security Unit. Aviation Security Unit inilah bekerja dengan memadukan berbagai aspek teknologi informasi yang saling berintegrasi, sebagai berikut:

1. Radar

2. Call Centre

3. Weather Info

4. Geographic Information System

5. Mobile

6. Kamera

7. Alert System

8. X-Ray

Sistem Aviation Security ini di kendalikan melalui ruang kontrol sistem keamanan bandara (room kontrol sistem airport safety) dan terhubung dengan delapan perangkat teknologi penerbangan yang telah di sebutkan diatas. Delapan perangkat ini saling terintegrasi dalam sistem sehingga membentuk sebuah sistem yang terkait satu dengan yang lain. Jika terjadi suatu kondisi kritis maka sistem akan menginstruksikan pihak-pihak yang harus melakukan pencegahan, evakuasi, maupun penanggulangan terhadap kondisi kritis tersebut. 
Aviation Security ini dikembangkan berdasarkan Standar Operasional Prosedur (SOP) yang telah ada di Bandar Binaka Gunungsitoli. Berikut merupakan SOP yang ada di bandara dan di integrasikan dalam sebuah aplikasi airport safety, berikut SOP penanggulangan kondisi kritis tersebut:

1. Penanggulangan Ancaman Bom

2. Penanggulangan Ancaman Bom Pada Pesawat Udara di Darat

3. Penanggulangan Ancaman Bom Pada Pesawat Udara di Udara.

4. Penanggulangan Ancaman Bom di Gedung, Objek Vital atau Fasilitas Lainnya di Bandara

5. Penanggulangan Bahan dan Barang Berbahaya

6. Penanggulangan Bencana Alam

7. Penanggulangan Insiden di Bandar Udara

8. Penanggulangan Keadaan Gawat Darurat Penuh

9. Penanggulangan Kebakaran Gedung

10. Penanggulangan Kebakaran Pesawat Udara di daerah Pergerakan Pesawat Udara

11. Penanggulangan Kecelakaan Pesawat Udara di Dalam Kawasan Bandar Udara

12. Penanggulangan Kecelakaan Pesawat Udara di Luar Kawasan Bandar Udara

13. Penanggulangan Kecelakaan Pesawat Udara di Perairan

14. Penanggulangan Status Siaga di Tempat

15. Penanggulangan Status Standby Cuaca Buruk

16. Penanggulangan Tindakan Melawan Hukum

Bila terjadi kondisi kritis, maka enam belas (16) SOP tersebut dapat diberlakukan. Sistem airport safety Bandar Udara Binaka Gunungsitoli dapat menangani kondisi kritis yang akan dikendalikan disebuah ruang kontrol dengan admin utama yang akan mengontrol dan menghubungi pihakpihak terkait hal tersebut. Selain itu pihak terkait dilengkapi radar menerima informasi dari admin yang mempermudah untuk ketahui posisi dari tempat kejadian tersebut. Adapun fitur-fitur yang menjadi pendukung dari sistem airport safety ini adalah:

1. Info Cuaca. Memberikan gambaran cuaca terkini sesuai dengan Badan Meteorologi, Klimaologi dan Geofisika (BMKG) wilayah Kota Gunungsitoli dan sekitarnya.

2. Kamera CCTV yang dapat di akses streaming, sebagai salah satu bentuk antisipasi kejadian dan tindak kriminal.

3. Alert system akan berfungsi sesuai dengan kondisi kritis yang terjadi pada pihak terkait dan terdekat.

4. Radar penerbangan, mengantisipasi ancaman penerbangan dari kondisi kritis baik kegagalan pendaratan maupun ancaman yang lainya.

5. Mobile Aplication sebagai salah satu bentuk Mapping lokasi dan mapping pihak pihak keaman terdekat untuk mempercepat tindakan antisipasi

6. Call Centre merupakan info nomor telepon terdekat dari kondisi kritis yang sesuai dengan kondisi kritis yang terjadai. Yaitu berupa sarana call centre terdekat dari jenis kejadian kritis yang terjadi.

\section{Hasil Wawancara} berikut :

Melalui wawancara yang telah dilakukan kepada responden maka diperoleh hasil sebagai

1. Sumber data yang digunakan dalam menangani gangguan keamanan Bandar Udara Binaka Gunungsitoli adalah dengan melakukan pemeriksaan langsung kepada setiap penumpang sesuai dengan standar operasioanal prosedur yang berlaku.

2. Dalam hal pengolahan data yang diperoleh sebagai dasar pengambilan keputusan, langkah pertama yang dilakukan oleh petugas keamanan Bandar Udara Binaka Gunungsitoli adalah memeriksa seluruh barang bawaan penumpang melalui mesin scan $x$-ray, kemudian pemeriksaan fisik penumpang melalui pintu detektor. Jika ditemukan ada penumpang yang melakukan pelanggaran atau tindakan yang mengganggu keamanan bandara dan penerbangan, 
maka petugas menyerahkannya kepada pimpinan aviation security untuk selanjutnya diambil tindakan.

3. Informasi yang dibutuhkan pihak pengamanan Bandar Udara Binaka Gunungsitoli dalam mengantisipasi berbagai gangguan keamanan saat ini yaitu petugas menara kontrol bandar udara Binaka Gunungsitoli menjelaskan bahwa sebelum aktivitas penerbangan dimulai, maka seluruh unit-unit yang ada di Bandar Udara Binaka Gunungsitoli harus saling koordinasi. Halhal yang dikoordinasikan adalah jenis penerbangan, jam penerbangan, kondisi cuaca di sekitar Bandar Udara Binaka Gunungsitoli, potensi gangguan keamanan serta manifest penerbangan. Semua poin ini harus bisa terkoordinasi dengan baik, supaya tidak terjadi pelanggaran atau tindakan-tindakan yang dapat merugikan semua pihak.

4. Setiap informasi yang diterima oleh pihak Bandar Udara Binaka Gunungsitoli wajib dikelola dengan baik. Petugas akan melakukan konfirmasi dan cek ulang informasi yang diperoleh agar tidak salah langkah dalam mengambil langkah antisipatif serta tindakan.

5. Tidak semua informasi yang didengar dan diperoleh dilakukan proses dan tindakan langsung, tergantung dari tingkat kerawanan yang ditimbulkan atau masuk dalam kategori gangguan keamanan ringan. Namun demikian bukan berarti informasi-informasi yang diperoleh diabaikan begitu saja.

6. Pihak-pihak yang terlibat dalam pengolahan informasi adalah pihak manajemen bandara yang terdiri dari pihak keamanan bandara dan pihak maskapai penerbangan.

7. Bentuk keputusan apa yang diambil oleh pimpinan dalam menangani gangguan keamanan bandar udara Binaka Gunungsitoli dilakukan secara tegas oleh kepala aviation security Bandar Udara Binaka Gunungsitoli, koordinator keamanan pintu masuk, koordinator keamanan check in, koordinator keamanan area pendaratan. Sikap dan keputusan petugas keamanan Bandar Udara Binaka Gunungstioli dalam menangani setiap gangguan keamanan harus tegas. Artinya, bahwa tidak toleransi bagi siapapun yang melakukan pelanggaran aturan yang telah ditetapkan.

8. Jenis sanksi yang diberikan kepada setiap pelaku pelanggaran adalah tindakan hukum.

9. Sistem Informasi Manajemen yang ada saat ini dapat mengantisipasi gangguan dalam bentuk kekerasan di bandar udara Binaka Gunungsitoli. Sistem informasi manajemen yang tersedia di Bandar Udara Binaka Gunungsitoli saat ini sudah cukup memadai, walaupun tidak sebanding dengan sistem informasi manajemen yang digunakan oleh bandar udara yang bertaraf internasional.

10. Alat-alat yang digunakan saat ini untuk mendukung kegiatan pengamanan Bandara Binaka Gunungsitoli sudah memadai walaupun masih ada kekurangan-kekurangan yang perlu dipenuhi dimasa yang akan datang.

11.Prosedur penanganan gangguan keamanan di bandar udara Binaka Gunungsitoli jika ada barang-barang terlarang diletak di dekat bandar udara. Dari jawaban responden dijelaskan bahwa setiap orang atau penumpang yang sudah memasuki area Bandar Udara Binaka Gunungsitoli wajib mematuhi seluruh prosedur yang berlaku di bandara. Mulai pintu gerbang masuk, pintu masuk check in, ruang tunggu penumpang bahwa sampai di Bandar Udara tujuan, penumpang diperiksa kode bagasinya.

12.Rentang koordinasi yang dilakukan dalam menangani setiap gangguan keamanan. Responden menjelaskan bahwa ada rentang koordinasi yang berlaku dalam menangani setiap gangguan keamanan. Contohnya, ketika ada penumpang yang membawa barang-barang terlarang (pisau, senjata tajam, senjata api, narkoba, bahan peledak, minuman beralkohol, dll). Petugas keamanan Bandar Udara Binaka Gunungsitoli hanya sebatas memeriksa dan mengidentifikasi, untuk selanjutnya jika terbukti bersalah, maka pihak keamanan bandara berkoordinasi dengan pihak kepolisian yang ada disekitar Bandar Udara Binaka Gunungsitoli.

13.Pihak yang terlibat secara langsung dalam penangangan gangguan keamanan. Responden menjawab bahwa pihak yang terlibat dalam penanganan gangguan keamanan bandara adalah pihak manajemen Bandar Udara Binaka Gunungsitoli dan pihak kepolisian. 
14. Kemudian tindakan yang dilakukan oleh petugas keamanan bandara jika terjadi gangguan keamanan dalam bentuk informasi palsu. Jawaban responden terkait pertanyaan ini, bahwa setiap informasi palsu yang ada, petugas melakukan pengecekan melalui sumber informasi. Sehingga pihak keamanan memiliki dasar yang kuat untuk melakukan langkah penindakan.

15. Bentuk-bentuk gangguan keamanan yang sudah pernah ditangani sampai saat ini, kepala keamanan Bandar Udara Binaka Gunungsitoli menjelaskan bahwa selama tahun 2017, sudah dilakukan beberapa penindakan kepada penumpung dan juga pengunjung terkait dengan gangguan keamanan bandara, misalnya: penumpang bawa minuman beralkohol (tuak), bawa senjata tajam (pisau), narkoba, penumpang mengaku bawa bom, boarding pass tidak sesuai dengan identitas penumpang, keributan di area bandara. Semua gangguan tersebut telah diproses oleh pihak manajemen Bandar Udara Binaka Gunungsitoli bekerjasama dengan pihak Kepolisian Resort Nias.

\section{Analisa Hasil Penelitian}

Berdasarkan hasil penelitian yang dilakukan melalui wawancara dan pengamatan, maka hasilnya diuraikan secara deskripsi. Peneliti akan menganalisa hasil penelitian terkait dengan Sistem Informasi Manajemen pada Unit Aviation Security Bandar Udara Binaka Gunungsitoli.

Bahwa Manajemen tidak dapat mengabaikan sistem informasi karena sistem informasi memainkan peran yang penting dalam organisasi. Sistem informasi ini sangat mempengaruhi secara langsung bagaimana manajemen mengambil keputusan, membuat rencana, dan mengelola para pegawainya, serta meningkatkan sasaran kinerja yang hendak dicapai, yaitu bagaimana menetapkan ukuran atau bobot setiap tujuan kegiatan, menetapkan standar pelayanan minimum, dan bagaimana menetapkan standar dan prosedur pelayanan baku kepada masyarakat. Oleh karenanya, tanggung jawab terhadap sistem informasi tidak dapat didelegasikan begitu saja kepada sembarang pengambil keputusan.

Semakin meningkatnya saling ketergantungan antara rencana strategis instansi, peraturan dan prosedur di satu sisi dengan sistem informasi (software, hardware, database, dan telekomunikasi) di sisi yang lainnya. Perubahan disatu komponen akan mempengaruhi komponen lainnya. Hubungan ini menjadi sangat kritikal manakala manajemen ingin membuat rencana ke depan. Aktivitas apa yang akan dilakukan untuk ke depan biasanya juga sangat tergantung kepada sistem apa yang tersedia untuk dapat melaksanakannya. Sebagai contoh, peningkatan produktivitas pengamanan bandar udara sangat tergantung pada jenis dan kualitas dari sistem informasi yang ada.

Perubahan lain dalam hubungan sistem informasi adalah dengan semakin meningkatnya cakupan dan ruang lingkup dari sistem informasi dan aplikasinya, maka akan mempermudah manajemen mengambil keputusan. Pengembangan dan pengelolaan sistem informasi dewasa ini membutuhkan keterlibatan banyak pihak di dalam organisasi. Sebagaimana sudah disampaikan dengan meningkatnya kecenderungan organisasi berteknologi digital, maka sistem informasi di dalam organisasi dapat meliputi jangkauan yang semakin luas hingga kepada masyarakat, instansi pemerintahan lainnya, dan bahkan informasi mengenai perkembangan politik terakhir.

Satu alasan mengapa sistem informasi memainkan peran yang sangat besar dan berpengaruh di dalam organisasi adalah karena semakin tingginya kemampuan teknologi komputer dan semakin murahnya biaya pemanfaatan teknologi komputer tersebut. Semakin baiknya kemampuan komputer telah menghasilkan jaringan komunikasi yang kuat yang dapat digunakan organisasi untuk melakukan akses informasi dengan cepat dari berbagai penjuru dunia serta untuk mengendalikan aktivitas yang tidak terbatas pada ruang dan waktu. Jaringan-jaringan ini telah mentransformasikan ketajaman dan bentuk aktivitas organisasi, menciptakan fondasi untuk memasuki era digital.

Sistem informasi pada Bandar Udara Binaka Gunungsitoli sangat memegang peranan penting sebab ianya merupakan pengendali utama yang mengatur ruang gerak dari aviation security pada Bandar Udara Binaka Gunungsitoli. Sistem informasi ini telah diatur dalam suatu Standar Operasional Prosedur (SOP) yang menjadi acuan dari airport safety. Sistem informasi 
inilah yang akan menginstruksikan pihak-pihak yang harus melakukan pencegahan, evakuasi, maupun penanggulangan terhadap kondisi kritis yang mungkin akan terjadi. Sebab didalam bandar udara ada beberapa daerah yang diklasifikasikan ke dalam daerah-daerah pengamanan, yaitu:

a. Daerah Tertutup.

b. Daerah Terbatas.

c. Daerah Publik (Public Area $=$ PA)

Jadi, tanpa sistem informasi yang baik akan sangat tidak mungkin untuk memberikan pengamanan pada ketiga daerah tersebut diatas.

\section{KESIMPULAN \& SARAN}

Dari hasil penelitian yang telah dilakukan diperoleh hasil bahwa sistem informasi manajemen Bandar Udara Binaka Gunungsitoli telah memenuhi standar pelayanan yang telah diatur dalam ketentuan penerbangan nasional. Standar operasional prosedur Aviation Security (Avsec) Bandara Binaka Gunungsitoli sangat memadai dan didukung oleh alat-alat teknologi canggih serta sudah mampu menangani gangguan keamanan dengan teknologi informasi yang ada. Keberhasilan Aviation Security Unit terbukti dimana penumpang bawa minuman beralkohol (tuak), bawa senjata tajam (pisau), narkoba, penumpang mengaku bawa bom, boarding pass tidak sesuai dengan identitas penumpang, keributan di area bandara bandara oleh oknum-oknum yang tidak bertanggung jawab. Telah diproses oleh pihak manajemen Bandar Udara Binaka Gunungsitoli bekerjasama dengan pihak Kepolisian Resort Nias untuk diproses sesuai dengan hukum yang berlaku.

Sebagai saran, diharapkan kepada pemerintah daerah di Kepulauan Nias agar memperhatikan peningkatan kapasitas dan sistem pengelolaan Bandar Udara Binaka Guningsitoli dimasa yang akan datang. Penerapan standar operasional prosedur sudah baik, namun perlu diperhatikan juga aspek-aspek etika dalam pelayanan kepada para pengguna jasa penerbangan. Selain itu perlu peningkatan kesadaran masyarakat disekitar Bandar Udara Binaka Gunungsitoli dalam keselamatan dan keamanan lingkungan area penerbangan, supaya tidak terjadi masalahmasalah yang mengakibatkan gangguan keamanan pada Bandar Udara Binaka Gunungsitoli. Dan yang terakhir perlu adanya sosialisasi secara terbuka kepada masyarakat penggunan moda transportasi udara ini tentang sistem informasi manajemen Bandar Udara Binaka Gunungsitoli yang dikemas dalam Standar operasional prosedur Aviation Security (Avsec) untuk menghindari terjadinya pelanggaran yang dapat mengakibatkan proses hukum.

\section{DAFTAR PUSTAKA}

Asmiarsih. (2014, Februari). e-jurnal. Dipetik Januari 8, 2020, dari Jenis-Jenis Disiplin Kerja: https://www.e-jurnal.com/2014/02/jenis-jenis-disiplin-kerja.html

Bugis, S. (2018). HUBUNGAN ANTARA KOMITMEN ORGANISASI DENGAN DISIPLIN KERJA PADA ANGGOTA LEMBAGA DAKWAH KAMPUS (LDK) DI YOGYAKARTA. Dipetik Januari 8, 2020, dari eprints.mercubuana-yogya: http://eprints.mercubuana-yogya.ac.id/id/eprint/3789

Diah Indriani Suwondo, E. M. (2015). Hubungan Lingkungan Kerja, Disiplin Kerja, dan Kinerja Karyawan. Jurnal Manajemen dan Kewirausahaan, 17.

Harahap, R. E. (2016). HUBUNGAN KEPEMIMPINAN TRANSFORMASIONAL DAN DISIPLIN KERJA DENGAN KINERJA PERAWAT RUMAH SAKIT TK.II PUTRI HIJAU MEDAN. Jurnal MAgister Psikologi UMA, 8.

Hendra Praja, G. a. (2017). ANALISIS DAMPAK PRODUKTIVITAS KERJA TERHADAP KESEJAHTERAAN KARYAWAN USAHA AYAM BROILER DALAM PERSPEKTIF EKONOMI ISLAM. Skripsi thesis, UNIVERSITAS ALMA ATA YOGYAKARTA. Dipetik Januari 9, 2020, dari elibrary.almaata: http://elibrary.almaata.ac.id/776/1/NASKAH\%20PUBLIKASI\%20GUSTARA.pdf 
Mauliya Siti Aisyah, T. A. (2019, Oktober 2). Analisis Disiplin Kerja Pada Sales Promotion Girl (SPG) dan Sales Promotion Boy (Studi KAsus Pada MDS PAragon Semarang). Jurnal Solusi .

Noviantari, O. (2017). Disipin Pegawai dalam Meningkatkan Kualitas Pelayanan Publik di Kantor Camat Siantar Kabupaten Simalungun. Dipetik Januari 9, 2020, dari repositori.usu: http://repositori.usu.ac.id/handle/123456789/3201

Pratiwi, M. (2018). Pengaruh Kedisiplinan dan Motivasi Kerja Terhadap Kinerja KAryawan PAda STIH Sumpah Pemuda Palembang. Dipetik Januari 8, 2020, dari eprints.polsri: http://eprints.polsri.ac.id/5991/3/BAB\%20II.pdf

Sembiring, T. (2016). Pengaruh Lingkungan Kerja Terhadap Produktivitas Kerja Pegawai Pada Direktorat Keuangan RSUP H. Adm Malik Medan. Dipetik Januari 9, 2020, dari repository.uma: http://repository.uma.ac.id/handle/123456789/881

Silalahi, S. P. (2017). Pengaruh Kedisiplinan Kerja dalam Meningkatkan Produktivitas Kerja Karyawan pada PT. Perkebunan Nusantara IV Kebun Tobasari. Jurnal Ilmiah Methonomi , 3, 14-21.

Sujarweni, V. W. (2015). Metodologi Penelitian Bisnis \& Ekonomi.

Sulfemi, W. (2018). Pengaruh disiplin Ibadah Sholat, lingkungan sekolah,dan intelegensi Terhadap Hasil Belajar Peserta Didik Mata Pelajaran Pendidikan Agama Islam. Jurnal Penelitian Pendidikan Agama dan Keagamaan, 16, 166-178.

Trihudiyatmanto, M. (2017). Pengaruh Motivasi Dan Kedisiplinan Kerja Terhadap Produktivitas Karyawan. Jurnal Penelitian Dan Pengabdian Kepada Masyarakat UNSIQ 4 (1) Tahun 2017 1, 20 $, 1,20$.

Yudapratama, A. (2017). Pengaruh Disiplin dan Kompensasi Terhadap Produktivitas Karyawan UKM Pada Sentra Sepatu Cibaduyut di Bandung. Dipetik Januari 9, 2020, dari repository.unpas: http://repository.unpas.ac.id/id/eprint/32794 